\title{
How does industry specialization affect the efficiency of regional innovation systems?
}

\author{
Michael Fritsch • Viktor Slavtchev
}

Received: 23 January 2009 / Accepted: 23 January 2009 / Published online: 22 February 2009

(C) The Author(s) 2009. This article is published with open access at Springerlink.com

\begin{abstract}
This study analyzes the relationship between the specialization of a region in certain industries and the efficiency of the region in generating new knowledge. The efficiency measure is constructed by relating regional R\&D input and output. An inversely u-shaped relationship is found between regional specialization and R\&D efficiency, indicating the presence of externalities of both Marshall and Jacobs' type. Further factors influencing efficiency are externalities resulting from high R\&D intensity of the local private sector as well as knowledge from local public research institutions. The impact of both the specialization and the additional factors is, however, different for regions at different efficiency levels.
\end{abstract}

JEL Classification $\mathrm{O} 31 \cdot \mathrm{O} 18 \cdot \mathrm{R} 12$

\section{Introduction}

The supposition that agglomerations are well suited for innovation activities has a long tradition in economics and economic geography. The idea behind this conjecture is

\footnotetext{
M. Fritsch ( $\square)$

School of Economics and Business Administration,

Friedrich Schiller University Jena, Carl-Zeiss-Str. 3, 07743 Jena, Germany

e-mail: m.fritsch@uni-jena.de

M. Fritsch

German Institute of Economic Research (DIW-Berlin), 10108 Berlin, Germany

M. Fritsch · V. Slavtchev

Max Planck Institute of Economics, Kahlaische Strasse 10, 07745 Jena, Germany

V. Slavtchev

e-mail: slavtchev@econ.mpg.de
} 
rather simple. First, innovative activities may be stimulated by the easy availability of inputs that is typical for agglomerated regions. Second, innovating firms are not isolated, self-sustained entities but rather are highly linked to their environment. Accordingly, innovative processes are characterized by pronounced degrees of labor division and knowledge flows so that spatial proximity to other innovating actors is important. Therefore, a certain degree of agglomeration or clustering of innovators within a particular area should be conducive to innovation activities (Porter 1998). In particular, there are two prominent hypotheses that pertain to the industry structure of the regional environment. One of these hypotheses states that the geographic concentration, i.e., the co-localization of firms that belong to the same industry or to related industries is conducive to innovation. Another hypothesis assumes that it is the diversity of industries and activities in a region, not the concentration in a certain industry that has a stimulating effect.

In this study, we test these two hypotheses by linking industry specialization of a region to its innovative performance. The next two sections elaborate on the theoretical background of the two hypotheses (Sect. 2) and review the empirical evidence attained thus far (Sect. 3). Section 4 introduces our concept of efficiency of a region in generating new knowledge, and Sect. 5 deals with data and measurement issues. We then give an overview on the efficiency of German regions (Sect. 6) and investigate the role of industry specialization (Sect. 7). Section 8 concludes.

\section{Why should industry specialization of a region stimulate or impede innovation?}

Innovation activity is characterized by interactions and flows of knowledge between actors and institutions. It can be regarded as a collective learning process taking place in a system of interconnected actors. The efficiency of the system may, therefore, be influenced by both the availability of actors as well as by the intensity of interaction and the respective knowledge flows. Interactions of a particular kind can occur between all the elements (or actors) constituting the system such as innovating private firms, public research institutes, suppliers of innovative inputs and services as well as public policy. For instance, the importance of backward and forward linkages has been pointed out by Kline (1985) and Kline and Rosenberg (1986), while Hippel (1986) and Urban and Hippel (1988) have referred particularly to the importance of lead users for inducing innovation. Hence, the density and industrial composition of the regional actors, the accessibility of the region as well as the technological, industrial, and institutional infrastructure may play an important role. Accordingly, differences in the socio-economic conditions that shape the creation of knowledge may lead to diverging innovative performance across regions (Cooke et al. 1997). Moreover, the interactions between the different elements of a regional innovation system (RIS) generate partly self-enforcing systemic effects that may result in region specific knowledge as well as in specific technologies and methods of problem solving (Gertler 2003), which can be expected to affect the workability of the system (Leydesdorff and Fritsch 2006). 
The specialization of a certain region in particular industries, typically measured by the co-location of a larger number of firms operating in similar or related technological fields is believed to be conducive to innovation activities of these firms since:

- the aggregate demand of a relatively large amount of firms of an industry may result in a pool of regional workforce with certain industry-specific skills that can be utilized by all firms belonging to that particular industry and located in the region (Marshall 1890; Ellison and Glaeser 1999);

- this aggregate demand of the regional firms can also induce a rich regional supply of other relevant inputs such as specialized business services, financial institutions or certain kinds of infrastructure (Bartelsman et al. 1994);

- the industry specialization of a region may stimulate intensive knowledge flows between the firms which are sharing the same technological base (Mowery et al. 1998; Beaudry and Breschi 2003);

- geographically bounded knowledge flows may be conductive for local collective learning processes (Lawson and Lorenz 1999; Maskell and Malmberg 1999).

These benefits of specialization within a certain industry are external to the firm belonging to that industry but remain largely internal to the particular region. Such effects that result from the specialization of regional economic activities in the same industry are labeled Marshall-Arrow-Romer externalities ${ }^{1}$ (MAR externalities) according to the authors who have made this concept popular (Glaeser et al. 1992).

However, the concentration of firms of the same industry in a region can also be disadvantageous if it leads to lock-in effects. Such lock-in effects may occur if the specialization of the regional knowledge and resources deter the emergence and evolution of other fields of innovation (Grabher 1993). In particular, narrow technological specialization may hamper the creation of novel knowledge. As argued by Jacobs (1969), many ingenious ideas are born in the exchange process that occurs between different fields of knowledge. This means that diversity may lead to advantages for innovation activity which are comprised of different, but complementary technological fields. Hence, it may be the industrial variety in a region that is conducive to innovation activity. Such effects of industrial variety are also labeled Jacobs' externalities and are supposed to be external to the firms and industries but internal to the respective geographical location. Moreover, as pointed out by Jacobs (1969), these effects can be expected to be greater in densely populated regions. Therefore, regions with diverse kinds of activities and a high degree of agglomeration, particularly cities, may have a comparative advantage over less densely populated areas which are usually characterized by a lesser variety of actors, institutions, and industries. Henderson (1997) shows for the USA that although a number of certain industries tend to be concentrated in agglomerations and large cities, these locations still remain more diversified.

\section{Empirical evidence}

The answer to the question if specialization or diversity in a region is conducive to innovation activity is still largely unclear. For example, Glaeser et al. (1992) found

\footnotetext{
1 Based on Marshall (1890), Arrow (1962), and Romer (1986).
} 
that diversity rather than regional specialization has a positive impact on employment growth in US-American cities. The study was, however, not directly linked to innovative activities. Feldman and Audretsch (1999) analyzed the effect of industry specialization on innovative output on the basis of innovation counts, which were attributed to four-digit SIC industries at the city level. The authors found that innovative output of an industry tends to be lower in cities which are specialized in that particular industry. This result supports the idea that diversity rather than specialization plays a major role. In other studies for the USA, Audretsch and Feldman (1996a,b) found that the geographical concentration of production is not a sufficient determinant for explaining the geographical concentration of innovative output. Obviously, Jacobs' thesis seems to hold for the US and can, according to Duranton and Puga (2000), be regarded as a stylized fact.

Many of the respective studies for European regions explicitly tested for both types of externalities. Paci and Usai (2000a) provided clear evidence for a significantly positive relationship between industry specialization and innovative output at the level of European NUTS-1 regions. The authors conclude that innovations occur in locations with pronounced manufacturing activities. However, there are typically a number of different knowledge sources (e.g., universities and other public R\&D laboratories) and other supporting facilities in such locations that are not included in their analysis. In the case of Italy, Paci and Usai (1999, 2000b) found evidence for both Jacobs' externalities as well as MAR externalities. With respect to the latter, the authors conclude that innovative activities in a certain industry, as measured by the number of patents, tend to be higher in geographic locations which are specialized in that particular industry. In a more recent study, Greunz (2004) tested the relationship between industry specialization and the number of patents at the level of European NUTS-2 regions and confirms these results. There is also some evidence from other European countries. For the Netherlands, van Oort (2002) and Ouwersloot and Rietveld (2000) found positive relationship between regional diversification and innovation in manufacturing industries. Also for the Netherlands, van der Panne (2004) identifies a positive relationship between regional specialization and the probability of firms to announce a new product, while diversification was insignificant. For Sweden, Andersson et al. (2005) conclude that there is a negative relationship between regional diversity and the innovative performance of firms. Also studies at the firm level provide ambiguous evidence (Baptista and Swann 1998; Beaudry and Breschi 2003).

Overall, previous analyses do not provide an unambiguous answer to the question whether industry specialization or diversity in a region stimulates innovation activities. In contrast to previous studies that focus on the impact of MAR- and Jacobs'externalities on the number of innovations or patents, we use the efficiency of regions in generating new knowledge as a performance indicator. Moreover, our analysis focuses not only on the role of specialization or diversity, but it also accounts for other key determinants of the efficiency of RIS.

\section{Assessing the efficiency of RIS}

The term efficiency is used in a variety of ways. Our understanding of the efficiency of RIS corresponds to the concept of technical efficiency as introduced by 
Farrell (1957). Technical efficiency is defined as the generation of a maximum output from a given amount of resources. A firm is regarded as being technically inefficient if it fails to obtain the possible maximum output. Reasons for technical inefficiency can be manifold and comprise all kinds of mismanagement such as inappropriate work organization and improper use of technology (Fritsch and Mallok 2002), bottlenecks in regard to certain inputs as well as X-inefficiency as exposed by Leibenstein (1966) seminal work. Applying this definition to a regional concept means that a region is technically efficient if it is able to produce a possible maximum of innovative output from a given amount of innovative input. Accordingly, the inefficiency of a region results from the failure to meet the best practice of conducting innovation activity.

We assume that inventions do not come out of thin air but result predominantly from systematic R\&D efforts, i.e.,

$$
\mathrm{R} \& \mathrm{D} \text { output }=f(\mathrm{R} \& \mathrm{D} \text { input })
$$

Adopting the Cobb-Douglas form of a production function (Griliches 1979; Jaffe 1989), the basic relationship between regional R\&D output and input can be written as

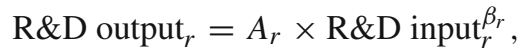

where the term $A$ represents a constant factor, $\beta$ denotes the output elasticity of the input to the R\&D process and $r$ is a regional index.

The output of the regional R\&D process may differ because of two reasons: the output elasticity of R\&D input, $\beta_{r}$, and the constant term, $A_{r}$. For example, an increase in the quality of inputs to the R\&D process or more pronounced spillovers from the $R \& D$ activities of other actors in the region may lead to a rising output elasticity of R\&D. Differences between regions in regard to the constant term indicate higher innovative output at any level of input. Such differences in the constant term may be explained by all kinds of characteristics of a region that influence average productivity of R\&D input but do not necessarily affect marginal productivity. Since, in practice, we are only able to assess the relevant knowledge stock rather incompletely, differences in regard to the constant term may also reflect a misspecification or incomplete measurement of the input variable. We, therefore, restrict ourselves here to the assessment based on the marginal productivity of R\&D input. Analyses of the two measures show that they lead to a quite similar assessment of the innovative performance of regions (Fritsch and Slavtchev 2006). ${ }^{2}$ Based on the estimates of the output elasticity of R\&D input in each region, the efficiency $E_{r}$ of the region $r$ is then calculated as

$$
E_{r}=\left(\hat{\beta}_{r} / \max \hat{\beta}_{r}\right) \times 100[\%]
$$

\footnotetext{
${ }^{2}$ See Fritsch and Slavtchev (2009a) for an alternative approach.
} 
According to this approach, at least one region will meet the benchmark value and the remaining regions will have efficiency values between 0 and $100 \%$ of this benchmark value. $^{3}$

\section{Data and measurement issues}

In this study, we use the number of disclosed corporate patent applications as an indicator of the innovative output of regions. The patent applications are assigned to the main residence of inventors. Information on the yearly number of disclosed patent applications is available for the 1995-2000 period from Greif and Schmiedl (2002). A patent application indicates that an invention has been made which is expected to have some economic value. However, using patents as an indicator of new knowledge has some shortcomings (Brouwer and Kleinknecht 1996; Acs et al. 2002; Griliches 1990). On the one hand, patents may underestimate the output of R\&D activity for several reasons. One of these reasons is that the results of basic research cannot be patented in Germany. Moreover, firms may not file all of their inventions for patenting or, in some cases, do not patent at all (Cohen et al. 2000). In this context, it is well known that firms tend to patent product innovations rather than process innovations. On the other hand, the actual R\&D output may also be overestimated on the basis of patent data in the event that the firms file blocking patents, which are typically applied around one core invention in a fairly new technological field and where there may be many potential applications which are not yet known. Although patents as an indicator of innovation have such shortcomings, we follow previous studies by assuming that patents are the best indicator of innovative output that is currently available.

Studies that analyze the innovation output of private firms at a regional level typically consider, in addition to corporate R\&D inputs, also a number of variables for determinants external to the firm such as university research, policy measures and regional characteristics (Fritsch and Slavtchev 2007, 2009b for details). The typically applied equation (cf. Eq. 2) does not actually indicate how firms internally innovate but rather implicitly assumes that such variables have direct impact on corporate innovation output. In our study we consider the number of private sector R\&D employees as the main knowledge input. We thereby assume that other factors such as public research, interregional spillovers, etc. which might be important for the innovative activities of local firms do not impact regional innovative output directly but rather operate through the local private sector R\&D employees. Information on the number of $R \& D$ employment in the private sector stems from the German Social Insurance Statistics (Statistik der sozialversicherungspflichtig Beschaeftigten) as described and documented by Fritsch and Brixy (2004). Employees are classified as working

\footnotetext{
3 However, as we consider that differences in the innovative performance of regions are only due to regional differences in the output elasticity of R\&D input, our measure of efficiency slightly differs from Farell's original concept (see for discussion Kalirajan and Shand 1999).
} 
in $R \& D$ if they have a tertiary degree and are employed as engineers or as natural scientists. $^{4}$

When relating knowledge input to innovation output we have to assume that there is a time lag between the respective indicators for two reasons. Firstly, R\&D activity requires time for attaining a patentable result (Griliches 1979). Secondly, patent applications are disclosed only about 12-18 months after submission (Greif and Schmiedl 2002). This is the time necessary for the patent office to verify whether an application fulfills the basic preconditions for being granted a patent. The patent application has to be disclosed 18 months after submission (Hinze and Schmoch 2004). Hence, at least 2-3 years should be an appropriate time lag between input and output of the R\&D process. ${ }^{5}$ However, since reliable data on R\&D employment in East Germany are only available for the years 1996 onwards, a time lag of 2 or 3 years would result in too few observations per region for estimating a region-specific efficiency. In order to have more observations available, we reduce the time lag between R\&D input and the patent application to a period of 1 year. ${ }^{6}$ In other words, R\&D output in the period from 1997 to 2000 is related to R\&D input between 1996 and 1999.

The spatial pattern used for the analysis is given by the 97 German planning regions. ${ }^{7}$ The spatial concept of planning regions considers commuter distances; therefore, they account for travel to work areas and are well suited to represent functional spatial economic entities. In general, planning regions consist of several districts and include at least one core city as well as its surroundings. For historical reasons, the cities of Berlin, Hamburg, and Bremen are defined as planning regions even though they are not functional economic units. In order to create functional units, we merge these cities with adjacent planning regions for the analysis. Berlin was merged with the region Havelland-Flaeming, Hamburg with the region Schleswig-Holstein South, Bremen with Bremerhaven and with the region Bremen-Umland. Hence, the estimation approach applied in this study is based on observations for 93 regions over 4 years.

To estimate the efficiency of regions, we include a binary dummy variable for each region, $D_{r}$, which is multiplied with the respective number of private sector R\&D employees. As this dummy variable assumes the value one for the respective region and otherwise has the value zero, the estimation of the region specific efficiency measure, $\beta_{r}$, can be done by using only one equation. The constant term, $A_{r}$, is assumed

\footnotetext{
4 Private sector employees with tertiary degree working as engineers or as natural scientists are only a proxy for the actual R\&D employees. However, this measure is highly correlated with the actual R\&D employees of private sector firms (about 0.95). Unfortunately, the actual number of private sector R\&D employees is not publicly available for the period of investigation in this study.

5 Fritsch and Slavtchev $(2006,2007)$ relate patenting activities in West Germany to R\&D activities 3 years ago. Acs et al. (2002) report that US innovation records in 1982 resulted from inventions that had been made 4.3 years earlier. Fischer and Varga (2003) use a 2-year lag between R\&D efforts and patent counts in Austria in 1993. Ronde and Hussler (2005) link the innovative output, the number of patents between 1997 and 2000, to R\&D efforts in 1997.

6 Bode (2004) also uses a time lag of 1 year when relating patent output to R\&D employment across German planning regions.

7 For this definition of the planning regions, see the Federal Office for Building and Regional Planning (Bundesamt fuer Bauwesen und Raumordnung, BBR 2003).
} 
to be the same for all regions $\left(A_{r}=A\right)$. Hence, after taking logarithms of both sides, the Eq. 2 can be rewritten as

$$
\ln \left(\text { Number of patents }_{r}\right)=\ln A+\sum_{r} \beta_{r} \times D_{r} \times \ln \left(\mathrm{R} \& \mathrm{D} \operatorname{priv}_{r}\right)+\varepsilon_{r}
$$

where $\beta_{r}$ is a measure of the output elasticity of private sector R\&D employment in the $r$ th region $(r=1, \ldots, 93)$. The output elasticity of $\mathrm{R} \& \mathrm{D}$ in the region, $\beta_{r}$, is estimated by means of robust negative-binomial regression technique. ${ }^{8}$ The data have been pooled. The efficiency measure, $E_{r}$, is then computed according to Eq. 3. The results are reported in Table 4 in the Appendix.

\section{The distribution of efficiency across German regions}

There is a wide dispersion of RIS efficiency among the planning regions. The values for efficiency are within the range between 53 and 100\%, meaning that productivity of private $R \& D$ input in the best practice region is about twice the productivity in the least efficient region (Fig. 1).

Generally, the efficiency values tend to be higher in regions with large, densely populated agglomerations such as Munich, Stuttgart, Cologne, Frankfurt, and Hamburg. The lowest efficiency estimates are found for regions in the northeast such as "Mecklenburgische Seenplatte", "Vorpommern", and "Altmark" located in East Germany, the former German Democratic Republic. The Berlin region, showing a relatively high efficiency, is an exception in the East German innovation landscape. The relatively low efficiency values in East Germany indicate that the innovation processes in this part of the country tend to be rather inefficient. Most of the relatively efficient regions are located in the southern and in the western part of the country. This suggests that the German innovation system is spatially divided into different regimes.

\section{Industry specialization and the efficiency of RIS}

To estimate the relative impact of different determinants of the efficiency of RIS, a robust OLS cross-section regression technique can be applied. A critical assumption of such an empirical approach is that whatever the sources of efficiency are, they operate identically in all regions whether they are highly efficient or not. However, the relative importance of the possible determinants of RIS's efficiency may differ for regions at different efficiency levels. We, therefore, apply simultaneous quantile regressions for analyzing this question. Differences in the effects between regions imply that the respective policy recommendations may only hold for certain types of regions.

\footnotetext{
8 See Greene (2003), pp 931-939. We find at least one patent per year for each region in our data; thus, the problem of having "too many zero values" does not apply. In the presence of over dispersion, i.e., the pronounced skewness to the left of the distribution of patent records, the negative binomial estimation technique is strongly favored over Poisson regression technique.
} 


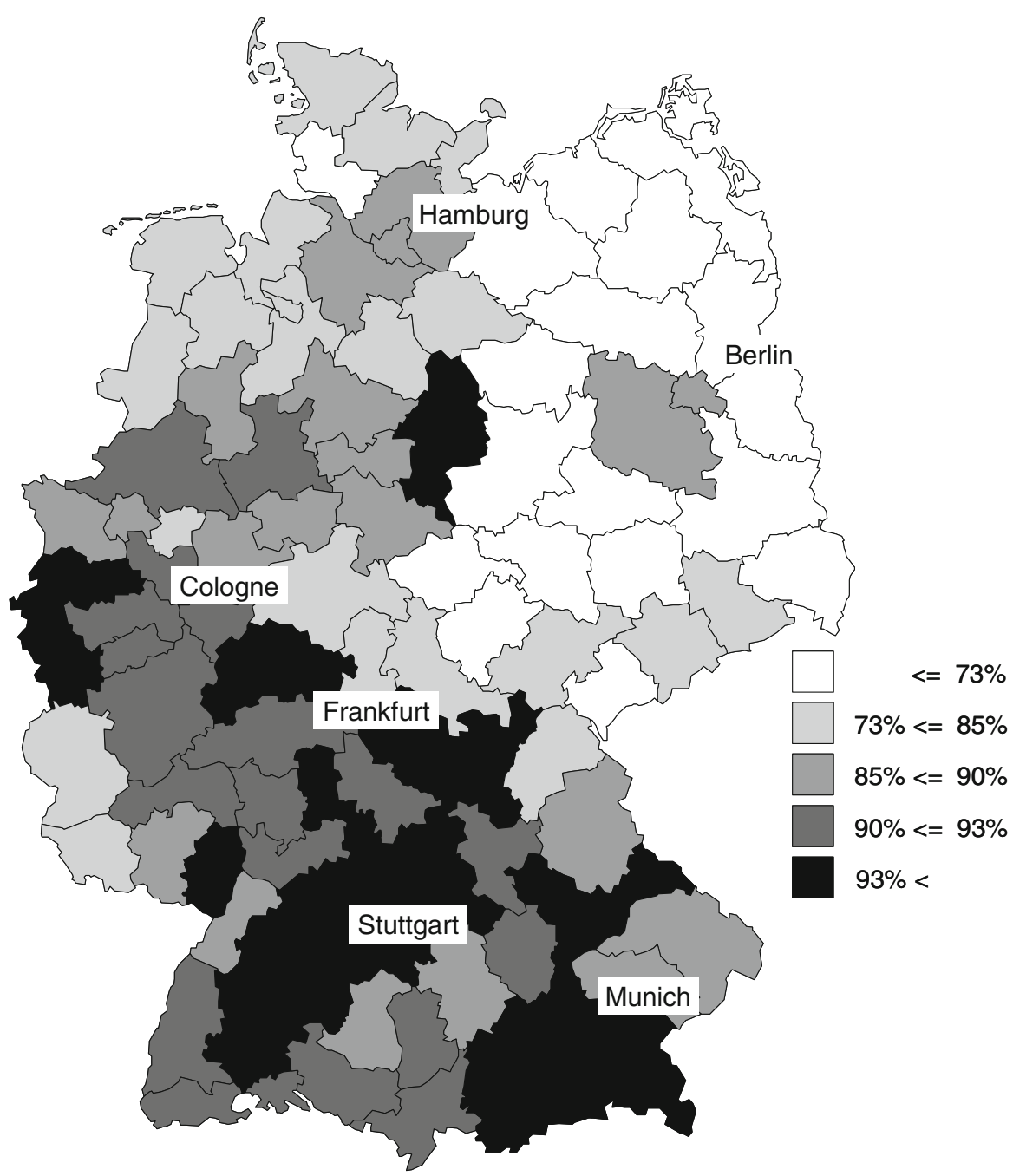

Fig. 1 The distribution of efficiency in German planning regions

Quantile regression was originally discussed in Koenker and Bassett (1982) and Rogers (1993) as a robust regression technique alternative to OLS. This technique differs from OLS in the estimation of the coefficients of the equation as it minimizes the sum of absolute error values rather than the sum of squared errors. More important for the problem here is that the coefficients can be estimated for a particular point $q$ in the distribution of the dependent variable:

$$
Q_{q}(y)=\alpha_{q}+\beta_{q, 1} x_{1}+\cdots+\beta_{q, n} x_{n} .
$$

Thus, assertions for different stages on the efficiency scale can be made. Although the estimated coefficients refer to a particular point in the distribution, all observations are used in calculating the coefficients for that particular quantile. For example, 
concerning median regression all residuals become equally weighted; while when fitting the $q$ th quantile, negative residuals are weighted by $2(1-q)$ and positive residuals by $2 q$. Here we apply a simultaneous quantile regression technique. The difference to a standard quantile regression is that the equations are estimated simultaneously and an estimate of the entire variance-covariance matrix is obtained by bootstrapping (Gould 1992). A main advantage of this method is that the estimated coefficients can be easily compared across equations (quantiles).

Although the main focus of this study is on the relationship between industry specialization in a region and productivity of $R \& D$ employment, a number of further important determinants of efficiency as well as a number of control variables are included. Table 1 gives an overview on the definition of variables and respective data sources. Descriptive statistics are presented in Table 2 while Table 3 shows the regression results. Correlation coefficients for the relationship between the variables are given in Table 5 in the Appendix.

A significantly positive impact on efficiency of RIS can be found for the share of private sector R\&D employment. The estimated coefficient provides evidence for scale economies. This means that an increase in the share of private sector R\&D

Table 1 Definition of variables and data sources

\begin{tabular}{|c|c|c|c|}
\hline Variable & Description & Definition & Source \\
\hline Patents & $\begin{array}{l}\text { Number of disclosed } \\
\text { patent applications in } \\
\text { the region, 1997-2000 }\end{array}$ & & $\begin{array}{l}\text { German Patent and } \\
\text { Trademark Office } \\
\text { (DPMA) }\end{array}$ \\
\hline R\&DPRIV & $\begin{array}{l}\text { Number of private sector } \\
\text { R\&D employees in the } \\
\text { region, 1996-1999 }\end{array}$ & $\begin{array}{l}\text { Number of employees with } \\
\text { tertiary degree working } \\
\text { as engineers or natural } \\
\text { scientists in the region }\end{array}$ & $\begin{array}{l}\text { German Social } \\
\text { Insurance Statistics }\end{array}$ \\
\hline Efficiency & $\begin{array}{l}\text { Efficiency of RIS, } \\
\text { 1997-2000 average }\end{array}$ & See Eq. 3 & See Eq. 3 \\
\hline R\&DPRIV (share) & $\begin{array}{l}\text { Share of private sector } \\
\text { R\&D employees in the } \\
\text { region, 1996-1999 } \\
\text { average }\end{array}$ & $\begin{array}{l}\text { Number of employees } \\
\text { with tertiary degree in } \\
\text { engineering and natural } \\
\text { sciences in the } \\
\text { region/number of } \\
\text { employees in the region }\end{array}$ & $\begin{array}{l}\text { German Social } \\
\text { Insurance Statistics }\end{array}$ \\
\hline TPFIND per professor & $\begin{array}{l}\text { Universities third-party } \\
\text { funds from private } \\
\text { companies per } \\
\text { professor in the region, } \\
\text { 1996-1999 average }\end{array}$ & $\begin{array}{l}\text { Volume of third-party } \\
\text { funds that universities in } \\
\text { the region gain from } \\
\text { private sector actors } \\
\text { [1,000 Euro]/number of } \\
\text { professors at universities } \\
\text { in the region }\end{array}$ & $\begin{array}{l}\text { German University } \\
\text { Statistics available } \\
\text { at the Federal } \\
\text { Statistical Office }\end{array}$ \\
\hline$\varnothing$ FSIZE & $\begin{array}{l}\text { Average firm size in the } \\
\text { region, 1996-1999 } \\
\text { average }\end{array}$ & $\begin{array}{l}\text { Number of employees in } \\
\text { the region/number of } \\
\text { firms in the region }\end{array}$ & $\begin{array}{l}\text { German Social } \\
\text { Insurance Statistics }\end{array}$ \\
\hline POPden & $\begin{array}{l}\text { Population density in the } \\
\text { region, 1996-1999 } \\
\text { average }\end{array}$ & $\begin{array}{l}\text { Number of inhabitants } \\
\text { per } \mathrm{km}^{2}\end{array}$ & $\begin{array}{l}\text { Federal Office for } \\
\text { Building and } \\
\text { Regional Planning }\end{array}$ \\
\hline
\end{tabular}


Table 1 continued

\begin{tabular}{|c|c|c|c|}
\hline Variable & Description & Definition & Source \\
\hline SERVICES & $\begin{array}{l}\text { Share of regional } \\
\text { employment in } \\
\text { services, } \\
\text { 1996-1999 average }\end{array}$ & $\begin{array}{l}\text { Number of regional } \\
\text { employees in } \\
\text { services/overall regional } \\
\text { employment }\end{array}$ & $\begin{array}{l}\text { German Social } \\
\text { Insurance Statistics }\end{array}$ \\
\hline ELECTR_ENG & $\begin{array}{l}\text { Share of employment in } \\
\text { electrical engineering } \\
\text { in the region, } \\
\text { 1996-1999 average }\end{array}$ & $\begin{array}{l}\text { Number of employees in } \\
\text { electrical engineering in } \\
\text { the region/number of } \\
\text { regional employment }\end{array}$ & $\begin{array}{l}\text { German Social } \\
\text { Insurance Statistics }\end{array}$ \\
\hline DIV & $\begin{array}{l}\text { Regional index of } \\
\text { industrial diversity, } \\
\text { 1996-1999 average }\end{array}$ & $\begin{array}{l}\text { Inverse of the } \\
\text { Donaldson-Weymark } \\
\text { relative S-Gini } \\
\text { coefficient on basis of } \\
\text { employment in } 58 \\
\text { industries (industrial } \\
\text { classification WZ58) }\end{array}$ & $\begin{array}{l}\text { German Social } \\
\text { Insurance Statistics }\end{array}$ \\
\hline Dummy West & $\begin{array}{l}\text { Region located in West } \\
\text { Germany }\end{array}$ & $\begin{array}{l}\text { Regions in former German } \\
\text { Federal Republic }=1 ; \\
\text { regions in former GDR } \\
\text { and Berlin }=0\end{array}$ & \\
\hline Dummy Periphery & $\begin{array}{l}\text { Region located at the } \\
\text { border of Germany }\end{array}$ & $\begin{array}{l}\text { Regions located at the } \\
\text { border of Germany }=1 \text {, } \\
\text { otherwise dummy }=0\end{array}$ & \\
\hline
\end{tabular}

Table 2 Descriptive statistics

\begin{tabular}{lcccccc}
\hline Variable & Observations & Mean & Median & $\begin{array}{c}\text { Standard } \\
\text { deviation }\end{array}$ & Minimum & Maximum \\
\hline Patents $^{\text {a }}$ & 372 & 395.50 & 245.75 & 508.60 & 11.778 & $3,652.7$ \\
R\&DPRIV $^{\text {a }}$ & 372 & $6,674.0$ & $3,690.0$ & $8,724.1$ & 649.00 & 48,968 \\
Marginal productivity & 93 & 0.6513 & 0.6768 & 0.0893 & 0.4119 & 0.7779 \\
$\quad$ of R\&DPRIV $(\hat{\beta})$ & & & & & & 100.00 \\
Efficiency $(\%)$ & 93 & 83.717 & 87.005 & 11.480 & 52.941 & 0.0528 \\
R\&DRIV (share) & 93 & 0.0223 & 0.0200 & 0.0089 & 0.0089 & 0.5227 \\
SERVICES & 93 & 0.3208 & 0.3118 & 0.0560 & 0.2203 & $3,886.29$ \\
POPden & 93 & 336.99 & 180.67 & 507.56 & 53.425 & 18.2661 \\
$\varnothing$ FSIZE & 93 & 13.204 & 13.308 & 1.6957 & 8.5294 & 97.067 \\
TPFIND per professor & 93 & 11.062 & 7.1950 & 14.735 & 0 & 1.6785 \\
DIV & 93 & 1.4979 & 1.5023 & 0.0825 & 1.3076 & 0.1227 \\
ELECTR_ENG & 93 & 0.0354 & 0.0292 & 0.0233 & 0.0038 & \\
\hline
\end{tabular}

a Pooled yearly values

employment at a certain location may make innovation processes more efficient. Such scale economies could result from increasing opportunities for R\&D cooperation and networking that are associated with intensive knowledge flows between actors and, 


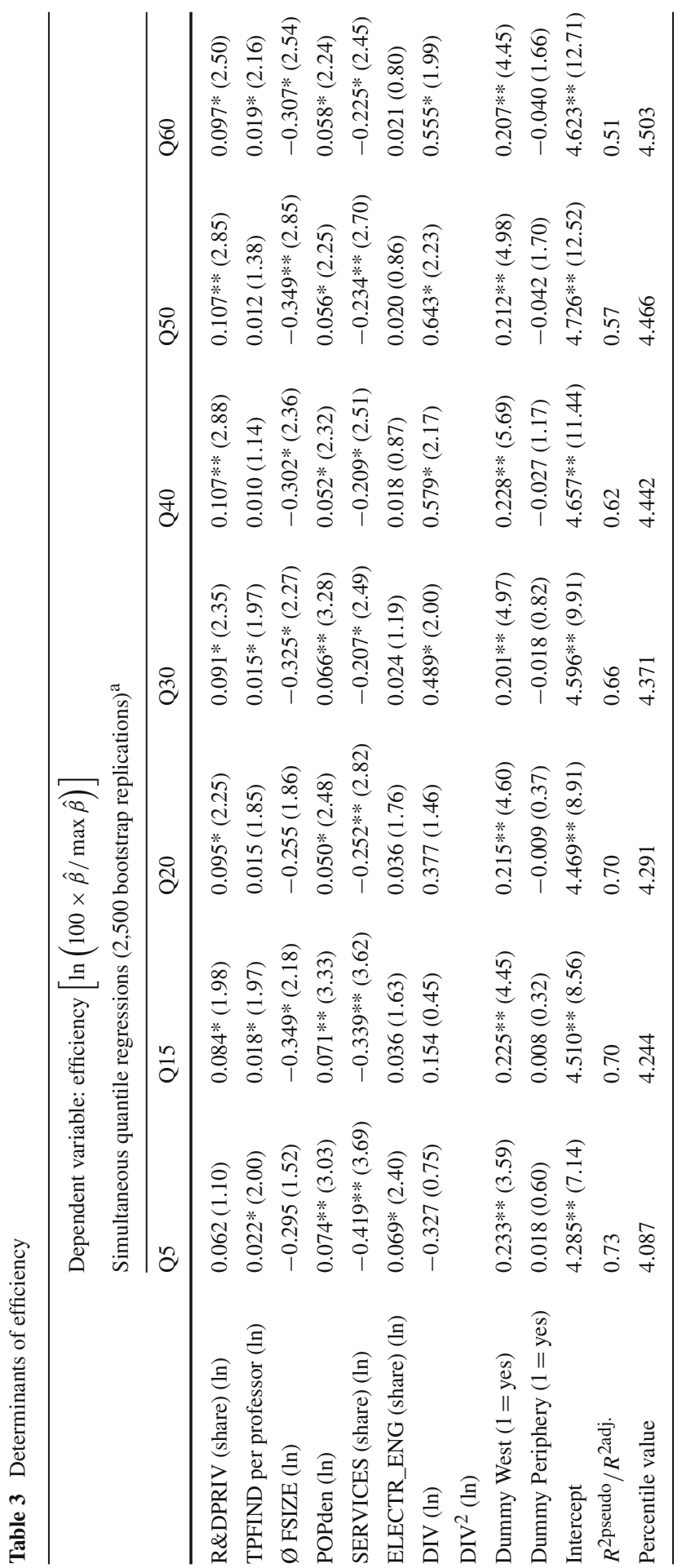




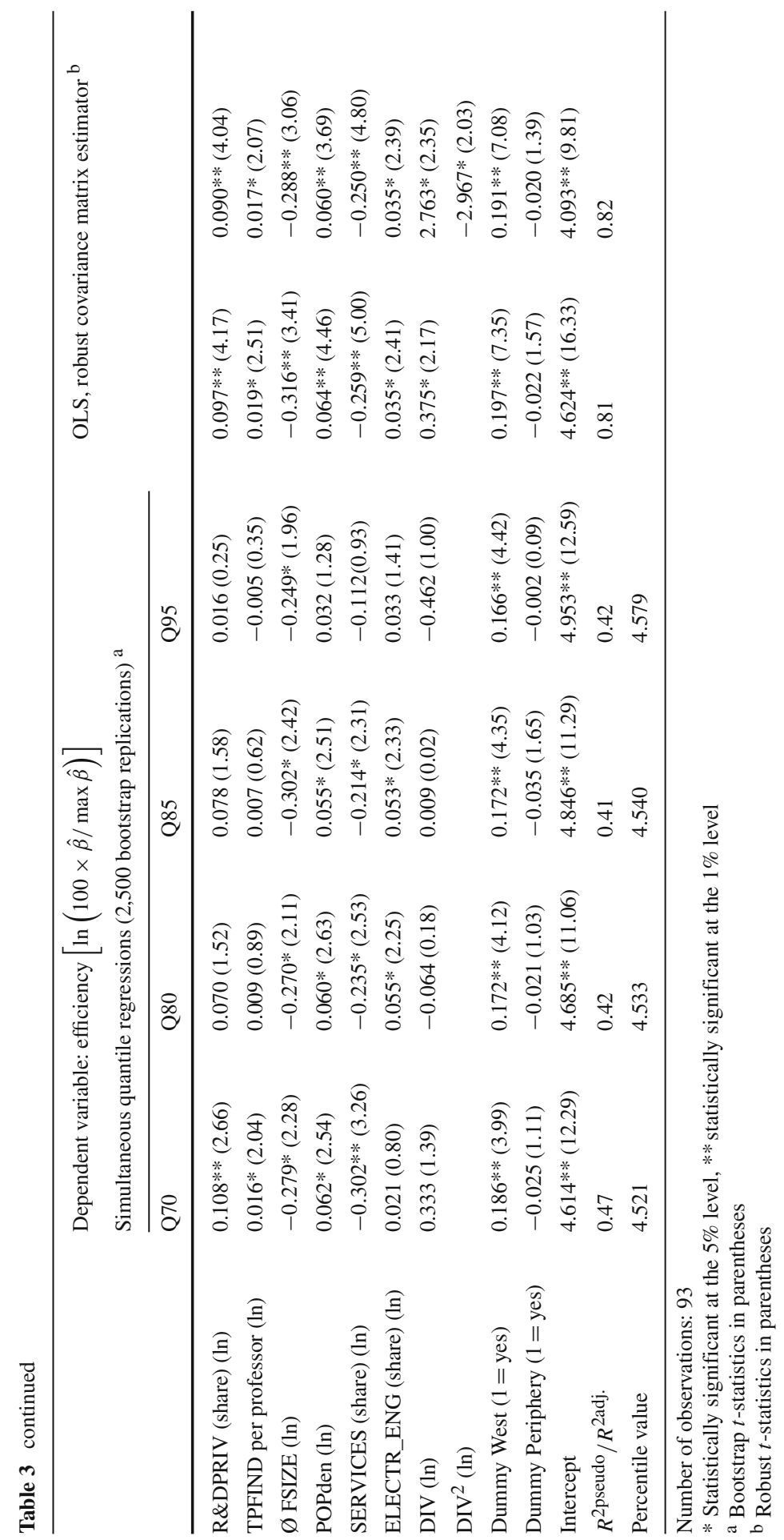


therefore, may lead to a relatively high level of productivity. However, as indicated by the quantile regressions, this pertains mainly to regions with a medium level of efficiency since regions at both ends of distribution do not seem to benefit from such positive externalities.

The average amount of third-party funds from private sector firms per university professor (TPFIND) has a positive impact on the RIS efficiency. Universities' third-party funds in general can be regarded as an indicator of the quality of their research. The main reason is that the allocation of universities' third-party funds is usually based on some competitive procedure and is, therefore, largely dependent on the quality of the research conducted. According to Hornbostel (2001), there is a distinct correspondence between indicators that are based on third-party funds and bibliometric indicators for high quality research such as SCI publications. Funds from private sector firms, in particular, can be regarded as compensation for academic R\&D or for other services that universities perform for private companies. Hence, these revenues are well suited to indicate the relevance of academic research for commercial applications as well as the intensity of formal university-industry linkages (Fritsch and Slavtchev 2007, 2009b). In order to avoid possible scale effects of large universities, which are likely to attract larger amounts of third-party funds from private firms, we use the average amount of third-party funds from private sector firms per university professor. Overall, the results for TPFIND suggest that the intensity of knowledge flows from universities due to formal university-industry linkages (e.g., R\&D contracts) is conducive to the efficiency of local corporate innovation activity. According to the quantile regressions, such a positive impact of university-industry relations on the efficiency of RIS is found for regions at the lower end and at the upper mid-range of the efficiency distribution. The impact of the intensity of university-industry interactions is less pronounced and becomes insignificant for regions with efficiency values belonging to the upper end of the distribution.

The industrial diversity index is the inverse value of the Gini coefficient calculated on the basis of the number of employees in 58 different industries. Considering the quantile regression approach, we find that the efficiency increases with industrial variety only for regions with relatively low efficiency up to the median value. According to Table 3, the estimated coefficients for industrial diversity are not statistically significant for relatively less efficient regions as well as for regions at the upper end of the distribution. This pattern suggests that the impact of the industrial diversity differs for regions at different efficiency levels (Fig. 2).

The OLS approach also provides evidence for nonlinear relationship between the degree of industrial diversity and the innovative performance of a region when introducing the inverse of the Gini coefficient and its squared value. ${ }^{9}$ The positive sign for the industrial diversity index suggests that the efficiency of regional innovation activity increases with the variety of industries in the region and that interaction of actors with different knowledge endowments stimulates the generation of new ideas rather than specialization (Jacobs' externalities). However, the negative sign for the

\footnotetext{
9 No relationship of third or higher polynomial order can be found between the degree of industrial diversity and efficiency. Furthermore, there is no significant relationship of second or higher polynomial order between any other explanatory variables and the efficiency.
} 

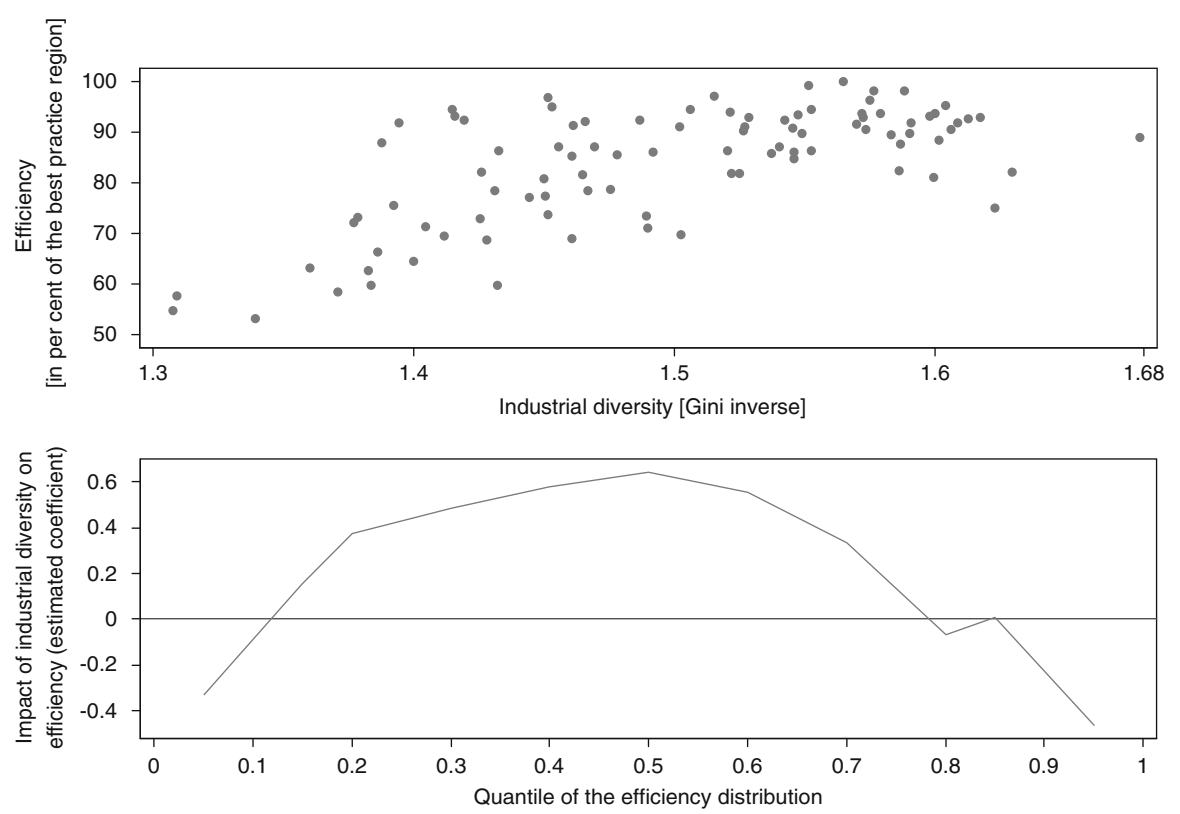

Fig. 2 Industrial variety and efficiency at the level of the German planning regions

squared value of the diversity index indicates a nonlinear relationship with the efficiency that has the shape of an inverse " $U$ " that is truncated close behind the maximum value. Indeed, the same pattern can be directly observed in the data (Fig. 2). ${ }^{10}$ This pattern implies that an optimum degree of industrial diversity exists and that a further increase beyond this level has an unfavorable effect. Obviously, both of the extremes, broad diversity as well as narrow specialization, may be unfavorable for the performance of a region. Even after introducing a number of additional variables in order to control for further effects, the estimated pattern for industrial diversity remains remarkably stable.

Our results suggest that externalities of both Marshall and Jacobs' type affect the efficiency of regions in producing innovative output. This confirms previous results of Paci and Usai $(1999,2000 b)$ who used the Herfindahl index as a measure of industrial diversity, and it also parallels the findings of Greunz (2004) who tested the impact of the industrial structure on innovation in European regions by means of Gini coefficients.

Because the specialization of a region in a certain industry with a relatively high level of patenting may significantly influence its innovative output and, therefore, the efficiency, a control for such industry-specific effects appears appropriate. Therefore, we account for the share of employees in the transportation engineering, electrical engineering, measurement engineering and optics, and chemistry, biochemistry inclusively. These are, according to Greif and Schmiedl (2002), the technological fields

\footnotetext{
10 High values of the Gini coefficient indicate high levels of industry diversification. Such an inverse "U"-shaped relationship between industrial diversity and efficiency may cause the insignificant coefficient estimated by means of quantile regression approach at the upper end of the distribution.
} 
in which most of the patent applications in Germany are generated. ${ }^{11}$ However, only regional specialization in electrical engineering appears to have a significant effect on RIS efficiency. The OLS approach as well as the quantile regressions suggest that there is a concentration of electrical engineering industry in high efficiency regions. The estimates for transportation engineering, measurement engineering, and optics as well as for chemistry are not statistically significant and, therefore, are not reported here.

Since firms in different industries tend to differ with respect to their minimum efficient size, we include the average firm size in the region in order to control for further industry-specific effects that are yet not captured. As indicated by the significantly negative coefficient for average firm size, efficiency of innovation activity tends to be lower in regions that are dominated by large scale industries. This confirms other studies which suggest that the number of patents per unit of R\&D input is higher in smaller firms than in larger ones (Acs and Audretsch 1990; Cohen and Klepper 1996).

Another common assumption in the innovation literature is that services, particularly knowledge intensive business services (KIBS), may produce and diffuse knowledge that is crucial for innovation processes (Muller and Zenker 2001; Anselin et al. 2000). In order to test the impact of the service supply in a region on the efficiency, we include the size of that sector (in terms of employment) into the model. However, our results indicate that the share of the service sector always has a negative impact on the efficiency of regions. This suggests that despite their supporting function, resources allocated to the service sector are less productive in terms of patenting (Bode 2004). This corresponds to the relatively low share of patents in services.

The positive coefficient for population density indicates the presence of urbanization economies. This means that densely populated regions provide a variety of opportunities for interaction in addition to often abundant supplies of input as well as a rich physical and institutional infrastructure, which may be advantageous for economic and innovation activity (Ciccone and Hall 1996; Crescenzi et al. 2007; Carlino et al. 2007).

The results of the analysis provide robust evidence that regions located in the western part of Germany are more efficient than regions located in the eastern part of the country. This suggests the presence of further region-specific factors (e.g., organization of the R\&D process, institutions, etc.) which also influence the efficiency of the R\&D processes. The statistically insignificant coefficient for the dummy variable for location at the periphery indicates that such regions do not tend to be relatively inefficient in comparison to the non-peripheral areas.

\section{Conclusions}

This study investigates the effect of a region's specialization in certain industries on its efficiency in producing knowledge. Our answer to the question "Is regional special-

\footnotetext{
11 In the 1995-2000 period, about $9.6 \%$ of all patent applications have been submitted in the field of transportation engineering, $13 \%$ in electrical engineering, and $7.4 \%$ in measurement engineering/optics (Greif and Schmiedl 2002).
} 
ization in a certain industry conducive to the innovative performance of regions?" is "Yes, but only to a certain degree". In fact, the analysis suggests that the relationship between specialization and the performance of a region has the form of an inverse "U". This means that the more a region specializes, the lesser contributes any further specialization to its efficiency.

The results of the quantile regressions indicate that the impact of different factors that determine the efficiency of RIS may not be identical at all levels of efficiency. In our analysis this pertained particularly to industrial diversity, to the amount of private sector $\mathrm{R} \& \mathrm{D}$, and to the intensity of university-industry knowledge transfer (as indicated by universities third-party funds from private sector firms). These results imply that there are no one-size-fits-all policy recommendations for stimulating the innovative performance in all kinds of regions. Clearly, policy should be well aware of regional idiosyncrasies and should properly account for region-specific factors.

The results of this study raise some important questions for further research. First, the determinants of knowledge spillovers within the private sector as well as the industry-universities relationships should be more illuminated, as such interactions seem to be conducive to the regional innovative performance. Second, additional research is required in order to answer the question about what the forces are that determine the industrial structure of regions. Moreover, regarding the role of industrial diversity for innovation, more information about the ways in which knowledge spills over between industries should be helpful in order to derive reasonable policy implications.

\section{Appendix}

Table 4 The distribution of efficiency in the German planning regions

\begin{tabular}{|c|c|c|c|c|c|}
\hline \multicolumn{2}{|l|}{ Planning region } & \multicolumn{2}{|c|}{$\begin{array}{l}\text { Estimated production } \\
\text { elasticities }\end{array}$} & \multirow{2}{*}{$\begin{array}{l}\text { Efficiency (\%) } \\
\frac{\hat{\beta}_{r}}{\max \hat{\beta}_{r}} \times 100\end{array}$} & \multirow[t]{2}{*}{ Rank } \\
\hline Code & Name & $\hat{\beta}_{r}$ & Robust std.error & & \\
\hline 1 & Schleswig-Holstein North & 0.5685 & 0.3012 & 73.07 & 75 \\
\hline 2 & Schleswig-Holstein South-West & 0.5412 & 0.2919 & 69.57 & 80 \\
\hline 3 & Schleswig-Holstein Central & 0.6104 & 0.2408 & 78.46 & 67 \\
\hline 4 & Schleswig-Holstein East & 0.5991 & 0.2639 & 77.02 & 70 \\
\hline 5 and 6 & $\begin{array}{l}\text { Schleswig-Holstein South } \\
\text { and Hamburg }\end{array}$ & 0.6657 & 0.1995 & 85.57 & 55 \\
\hline 7 & Western Mecklenburg & 0.4634 & 0.2534 & 59.57 & 88 \\
\hline 8 & Central Mecklenburg/Rostock & 0.5163 & 0.2524 & 66.37 & 84 \\
\hline 9 & Western Pomerania & 0.4479 & 0.2558 & 57.58 & 91 \\
\hline 10 & Mecklenburgische Seenplatte & 0.4119 & 0.2737 & 52.94 & 93 \\
\hline 11,13 and 15 & $\begin{array}{l}\text { Bremen and Bremerhaven and } \\
\text { Bremen-Umland }\end{array}$ & 0.6123 & 0.2170 & 78.71 & 66 \\
\hline 12 & East Frisian & 0.5866 & 0.2777 & 75.41 & 71 \\
\hline
\end{tabular}


Table 4 continued

\begin{tabular}{|c|c|c|c|c|c|}
\hline \multicolumn{2}{|c|}{ Planning region } & \multicolumn{2}{|c|}{$\begin{array}{l}\text { Estimated production } \\
\text { elasticities }\end{array}$} & \multirow{2}{*}{$\begin{array}{l}\text { Efficiency (\%) } \\
\frac{\hat{\beta}_{r}}{\max \hat{\beta}_{r}} \times 100\end{array}$} & \multirow[t]{2}{*}{ Rank } \\
\hline Code & Name & $\hat{\beta}_{r}$ & Robust std. error & & \\
\hline 14 & Hamburg-Umland-South & 0.6778 & 0.2669 & 87.12 & 46 \\
\hline 16 & Oldenburg & 0.6008 & 0.2683 & 77.22 & 69 \\
\hline 17 & Emsland & 0.5823 & 0.2705 & 74.85 & 72 \\
\hline 18 & Osnabruck & 0.6767 & 0.2550 & 86.99 & 48 \\
\hline 19 & Hanover & 0.6691 & 0.2136 & 86.01 & 53 \\
\hline 20 & Suedheide & 0.6290 & 0.2780 & 80.85 & 65 \\
\hline 21 & Luneburg & 0.5726 & 0.3003 & 73.60 & 73 \\
\hline 22 & Brunswick & 0.7250 & 0.2178 & 93.19 & 18 \\
\hline 23 & Hildesheim & 0.6713 & 0.2566 & 86.29 & 50 \\
\hline 24 & Gottingen & 0.6817 & 0.2601 & 87.62 & 45 \\
\hline 25 & Prignitz-Obehavel & 0.4859 & 0.2630 & 62.46 & 87 \\
\hline 26 & Uckermark-Barnim & 0.4542 & 0.2716 & 58.38 & 90 \\
\hline 27 & Oderland-Spree & 0.4899 & 0.2574 & 62.98 & 86 \\
\hline 28 & Lusatia-Spreewald & 0.5389 & 0.2314 & 69.28 & 81 \\
\hline 29 and 30 & Havelland-Flaeming and Berlin & 0.6833 & 0.1915 & 87.83 & 44 \\
\hline 31 & Altmark & 0.4247 & 0.3065 & 54.59 & 92 \\
\hline 32 & Magdeburg & 0.5550 & 0.2300 & 71.34 & 78 \\
\hline 33 & Dessau & 0.4634 & 0.2474 & 59.56 & 89 \\
\hline 34 & Halle/Saale & 0.5604 & 0.2273 & 72.04 & 77 \\
\hline 35 & Muenster & 0.7112 & 0.2255 & 91.42 & 31 \\
\hline 36 & Bielefeld & 0.7150 & 0.2233 & 91.91 & 28 \\
\hline 37 & Paderborn & 0.6673 & 0.2556 & 85.78 & 54 \\
\hline 38 & Arnsberg & 0.6692 & 0.2516 & 86.03 & 52 \\
\hline 39 & Dortmund & 0.6403 & 0.2276 & 82.31 & 58 \\
\hline 40 & Emscher-Lippe & 0.6768 & 0.2413 & 87.01 & 47 \\
\hline 41 & Duisburg/Essen & 0.6714 & 0.2077 & 86.31 & 49 \\
\hline 42 & Duesseldorf & 0.7335 & 0.1964 & 94.29 & 12 \\
\hline 43 & Bochum/Hagen & 0.7171 & 0.2215 & 92.18 & 26 \\
\hline 44 & Cologne & 0.7018 & 0.2008 & 90.21 & 38 \\
\hline 45 & Aachen & 0.7237 & 0.2235 & 93.02 & 19 \\
\hline 46 & Bonn & 0.7149 & 0.2418 & 91.90 & 29 \\
\hline 47 & Siegen & 0.7049 & 0.2571 & 90.61 & 35 \\
\hline 48 & Northern Hesse & 0.6353 & 0.2399 & 81.66 & 62 \\
\hline 49 & Central Hesse & 0.7282 & 0.2366 & 93.61 & 15 \\
\hline 50 & Eastern Hesse & 0.6306 & 0.2843 & 81.07 & 64 \\
\hline 51 & Rhine-Main & 0.7107 & 0.1920 & 91.36 & 32 \\
\hline 52 & Starkenburg & 0.7185 & 0.2141 & 92.35 & 25 \\
\hline 53 & Northern Thuringia & 0.5008 & 0.2697 & 64.37 & 85 \\
\hline
\end{tabular}


Table 4 continued

\begin{tabular}{|c|c|c|c|c|c|}
\hline \multicolumn{2}{|c|}{ Planning region } & \multicolumn{2}{|c|}{$\begin{array}{l}\text { Estimated production } \\
\text { elasticities }\end{array}$} & \multirow{2}{*}{$\begin{array}{l}\text { Efficiency (\%) } \\
\frac{\hat{\beta}_{r}}{\max \hat{\beta}_{r}} \times 100\end{array}$} & \multirow[t]{2}{*}{ Rank } \\
\hline Code & Name & $\hat{\beta}_{r}$ & Robust std. error & & \\
\hline 54 & Central Thuringia & 0.5658 & 0.2296 & 72.74 & 76 \\
\hline 55 & Southern Thuringia & 0.5698 & 0.2540 & 73.24 & 74 \\
\hline 56 & Eastern Thuringia & 0.6349 & 0.2354 & 81.61 & 63 \\
\hline 57 & Western Saxony & 0.5347 & 0.2171 & 68.74 & 83 \\
\hline 58 & Upper Elbe Valley/Eastern Ore Mountains & 0.6387 & 0.2132 & 82.10 & 59 \\
\hline 59 & Upper Lusatia-Lower Silesia & 0.5356 & 0.2440 & 68.85 & 82 \\
\hline 60 & Chemnitz-Ore Mountains & 0.6087 & 0.2254 & 78.25 & 68 \\
\hline 61 & South West Saxony & 0.5520 & 0.2446 & 70.96 & 79 \\
\hline 62 & Middle Rhine-Nahe & 0.7033 & 0.2385 & 90.40 & 37 \\
\hline 63 & Trier & 0.6370 & 0.2847 & 81.89 & 61 \\
\hline 64 & Rhine-Hesse-Nahe & 0.7220 & 0.2427 & 92.81 & 22 \\
\hline 65 & Western Palatinate & 0.6619 & 0.2659 & 85.08 & 56 \\
\hline 66 & Rhine Palatinate & 0.7339 & 0.2229 & 94.34 & 11 \\
\hline 67 & Saar & 0.6591 & 0.2354 & 84.73 & 57 \\
\hline 68 & Upper Neckar & 0.7084 & 0.2137 & 91.06 & 33 \\
\hline 69 & Franconia & 0.7292 & 0.2348 & 93.73 & 14 \\
\hline 70 & Middle Upper Rhine & 0.6975 & 0.2158 & 89.66 & 40 \\
\hline 71 & Northern Black Forest & 0.7631 & 0.2490 & 98.09 & 3 \\
\hline 72 & Stuttgart & 0.7556 & 0.1869 & 97.13 & 5 \\
\hline 73 & Eastern Wuertemberg & 0.7631 & 0.2459 & 98.09 & 4 \\
\hline 74 & Danube-Iller (BW) & 0.6950 & 0.2373 & 89.34 & 41 \\
\hline 75 & Neckar-Alb & 0.7295 & 0.2390 & 93.77 & 13 \\
\hline 76 & Black Forest-Baar-Heuberg & 0.7498 & 0.2501 & 96.39 & 7 \\
\hline 77 & Southern Upper Rhine & 0.7141 & 0.2344 & 91.80 & 30 \\
\hline 78 & High Rhine-Lake Constance & 0.7226 & 0.2397 & 92.88 & 20 \\
\hline 79 & Lake Constance-Upper Swabia & 0.7198 & 0.2282 & 92.53 & 23 \\
\hline 80 & Bavarian Lower Main & 0.7254 & 0.2604 & 93.24 & 17 \\
\hline 81 & Wurzburg & 0.7083 & 0.2495 & 91.05 & 34 \\
\hline 82 & Main-Rhone & 0.7531 & 0.2603 & 96.81 & 6 \\
\hline 83 & Upper Franconia-West & 0.7407 & 0.2558 & 95.21 & 8 \\
\hline 84 & Upper Franconia-East & 0.6377 & 0.2599 & 81.97 & 60 \\
\hline 85 & Upper Franconia-North & 0.6868 & 0.2669 & 88.28 & 43 \\
\hline 86 & Industrial Region Central Franconia & 0.7167 & 0.2021 & 92.13 & 27 \\
\hline 87 & Augsburg & 0.7281 & 0.2885 & 93.60 & 16 \\
\hline 88 & Western Central Franconia & 0.6910 & 0.2305 & 88.83 & 42 \\
\hline 89 & Ingolstadt & 0.7189 & 0.2545 & 92.40 & 24 \\
\hline 90 & Regensburg & 0.7354 & 0.2384 & 94.53 & 10 \\
\hline 91 & Danube-Forest & 0.6984 & 0.2658 & 89.78 & 39 \\
\hline
\end{tabular}


Table 4 continued

\begin{tabular}{|c|c|c|c|c|c|}
\hline \multicolumn{2}{|c|}{ Planning region } & \multicolumn{2}{|c|}{$\begin{array}{l}\text { Estimated production } \\
\text { elasticities }\end{array}$} & \multirow{2}{*}{$\begin{array}{l}\text { Efficiency }(\%) \\
\frac{\hat{\beta}_{r}}{\max \hat{\beta}_{r}} \times 100\end{array}$} & \multirow[t]{2}{*}{ Rank } \\
\hline Code & Name & $\hat{\beta}_{r}$ & Robust std. error & & \\
\hline 92 & Landshut & 0.6713 & 0.2702 & 86.29 & 51 \\
\hline 93 & Munich & 0.7379 & 0.1868 & 94.85 & 9 \\
\hline 94 & Danube-Iller (BY) & 0.7223 & 0.2578 & 92.85 & 21 \\
\hline 95 & Allgaeu & 0.7041 & 0.2612 & 90.51 & 36 \\
\hline 96 & Oberland & 0.7779 & 0.2693 & 100.00 & 1 \\
\hline 97 & Southeast Upper Bavaria & 0.7723 & 0.2441 & 99.27 & 2 \\
\hline
\end{tabular}

Results of robust (cluster) negative-binomial regression. Estimated INTERCEPT $=-0.0225$, robust standard error $=2.0049$. Log pseudolikelihood $=-1,749.86$

Table 5 Correlation of variables

\begin{tabular}{|c|c|c|c|c|c|c|c|c|c|}
\hline & Variable & 1 & 3 & 4 & 5 & 6 & 7 & 8 & 9 \\
\hline 1 & Patents $^{\mathrm{a}}$ & & & & & & & & \\
\hline 2 & R\&DPRIV ${ }^{\mathrm{a}}$ & 0.92 & & & & & & & \\
\hline 3 & Efficiency & & 1.00 & & & & & & \\
\hline 4 & R\&DPRIV (share) & & 0.22 & 1.00 & & & & & \\
\hline 5 & SERVICES & & 0.08 & 0.44 & 1.00 & & & & \\
\hline 6 & POPden & & 0.17 & 0.38 & 0.47 & 1.00 & & & \\
\hline 7 & $\varnothing$ FSIZE & & 0.08 & 0.58 & 0.19 & 0.46 & 1.00 & & \\
\hline 8 & TPFIND per professor & & 0.23 & 0.33 & 0.20 & 0.04 & 0.20 & 1.00 & \\
\hline 9 & DIV & & 0.66 & -0.09 & -0.12 & -0.05 & -0.05 & 0.10 & 1.00 \\
\hline 10 & ELECTR_ENG & & 0.55 & 0.26 & -0.11 & 0.02 & 0.18 & 0.21 & 0.44 \\
\hline
\end{tabular}

a Pooled yearly values

Open Access This article is distributed under the terms of the Creative Commons Attribution Noncommercial License which permits any noncommercial use, distribution, and reproduction in any medium, provided the original author(s) and source are credited.

\section{References}

Acs ZJ, Audretsch DB (1990) Innovation and small firms. Cambridge University Press, Cambridge

Acs ZJ, Anselin L, Varga A (2002) Patents and innovation counts as measures of regional production of new knowledge. Res Policy 31:1069-1085. doi:10.1016/S0048-7333(01)00184-6

Andersson R, Quigley JM, Wilhelmsson M (2005) Agglomeration and the spatial distribution of creativity. Pap Reg Sci 84:445-464. doi:10.1111/j.1435-5957.2005.00049.x

Anselin L, Varga A, Acs ZJ (2000) Geographic and sectoral characteristics of academic knowledge externalities. Pap Reg Sci 79:435-443. doi:10.1007/PL00011486

Arrow KJ (1962) The economic implications of learning by doing. Rev Econ Stud 29:155-173. doi: $10.2307 / 2295952$

Audretsch DB, Feldman MP (1996a) R\&D spillovers and the geography of innovation and production. Am Econ Rev 86:631-640 
Audretsch DB, Feldman MP (1996b) Innovative clusters and the industry life cycle. Rev Ind Organ 11: 253-273. doi:10.1007/BF00157670

Baptista R, Swann P (1998) Do firms in clusters innovate more? Res Policy 27:525-540. doi:10.1016/S0048-7333(98)00065-1

Bartelsman EJ, Caballero RJ, Lyons RK (1994) Customer- and supplier-driven externalities. Am Econ Rev $84: 1075-1084$

Beaudry C, Breschi S (2003) Are firms in clusters really more innovative? Econ Innov N Technol 12: 325-342. doi:10.1080/10438590290020197

Bode E (2004) The spatial pattern of localized R\&D spillovers: an empirical investigation for Germany. J Econ Geogr 4:43-64. doi:10.1093/jeg/4.1.43

Brouwer E, Kleinknecht A (1996) Determinants of innovation: a microeconomic analysis of three alternative innovation indicators. In: Kleinknecht A (ed) Determinants of innovation: the message from new indicators. Macmillan, Basingstoke

Bundesamt fuer Bauwesen und Raumordnung_BBR (2003) Aktuelle Daten zur Entwicklung der Staedte, Kreise und Gemeinden 17. BBR, Bonn

Carlino GA, Chatterjee S, Hunt RM (2007) Urban density and the rate of invention. J Urban Econ 61: 389-419. doi:10.1016/j.jue.2006.08.003

Ciccone A, Hall RE (1996) Productivity and the density of economic activity. Am Econ Rev 86:54-70

Cohen WM, Klepper S (1996) A reprise of size and R\&D. Econ J 106:925-951. doi:10.2307/2235365

Cohen WM, Nelson RR, Walsh JP (2000) Protecting their intellectual assets: appropriability conditions and why US manufacturing firms patent (or not). NBER working paper series no. 7552

Cooke P, Uranga MG, Etxebarria G (1997) Regional innovation systems: institutions and organisational dimensions. Res Policy 26:475-491. doi:10.1016/S0048-7333(97)00025-5

Crescenzi R, Rodriguez-Pose A, Storper M (2007) The territorial dynamics of innovation: a Europe-United States comparative analysis. J Econ Geogr 7:673-709. doi:10.1093/jeg/lbm030

Duranton G, Puga D (2000) Diversity and specialization in cities. Why, where and when does it matter? Urban Stud 37:533-555. doi:10.1080/0042098002104

Ellison G, Glaeser EL (1999) The geographic concentration of industry: does natural advantages explain agglomeration. Am Econ Rev 89:301-316

Farrell MJ (1957) The measurement of productive efficiency. J R Stat Soc Ser A 120:253-282. doi:10.2307/ 2343100

Feldman MP, Audretsch DB (1999) Innovation in cities: science-base diversity, specialization and localized competition. Eur Econ Rev 43:409-429. doi:10.1016/S0014-2921(98)00047-6

Fischer MM, Varga A (2003) Spatial knowledge spillovers and university research: evidence from Austria. Ann Reg Sci 37:303-322. doi:10.1007/s001680200115

Fritsch M, Mallok J (2002) Machinery and productivity-A comparison of East and West German manufacturing plants. In: Schaetzl L, Diez JR (eds) Technological change and regional development in Europe. Physica, Berlin

Fritsch M, Brixy U (2004) The establishment file of the German social insurance statistics. Schmollers Jahrbuch/J Appl Soc Sci Stud 124:183-190

Fritsch M, Slavtchev V (2006) Measuring the efficiency of regional innovation systems-an empirical assessment. Working paper 8/2006, Faculty of Economics and Business Administration. Technical University Bergakademie Freiberg, Freiberg

Fritsch M, Slavtchev V (2007) Universities and innovation in Space. Ind Innov 14:201-218. doi:10.1080/ 13662710701253466

Fritsch M, Slavtchev V (2009a) Determinants of the efficiency of regional innovation systems. Reg Stud (forthcoming). doi:10.1080/00343400802251494

Fritsch M, Slavtchev V (2009b) Local knowledge sources, spillovers and innovation, School of Economics and Business Administration. Friedrich-Schiller-University Jena, Germany

Gertler MS (2003) Tacit knowledge and the economic geography of context, or the undefinable tacitness of being (there). J Econ Geogr 3:75-99. doi:10.1093/jeg/3.1.75

Glaeser EL, Kallal HD, Scheinkam JA, Shleifer A (1992) Growth in cities. J Polit Econ 100:1126-1152. doi:10.1086/261856

Gould WW (1992) Quantile regression with bootstrapped standard errors. Stata Tech Bull 9:19-21

Grabher G (1993) The weakness of strong ties: the lock-in of regional developments in the Ruhr area. In: Grabher G (ed) The embedded firm—on the socioeconomics of industrial networks. Routledge, London 
Greene WH (2003) Econometric analysis. Prentice Hall, New York

Greif S, Schmiedl D (2002) Patentatlas Deutschland. Deutsches Patent- und Markenamt, Munich

Greunz L (2004) Industrial structure and innovation-evidence from European regions. J Evol Econ 14: 563-592. doi:10.1007/s00191-004-0234-8

Griliches Z (1979) Issues in assessing the contribution of research and development to productivity growth. Bell J Econ 10:92-116. doi:10.2307/3003321

Griliches Z (1990) Patent statistics as economic indicators: a survey. J Econ Lit 28:1661-1707

Henderson V (1997) Medium size cities. Reg Sci Urban Econ 27:583-612. doi:10.1016/ S0166-0462(96)02169-2

Hinze S, Schmoch U (2004) Analytical approaches and their impact on the outcome of statistical patent analysis. In: Moed HF, Glaenzel W, Schmoch U (eds) Handbook of quantitative science and technology research: the use of publication and patent statistics in studies of S\&T systems. Kluwer, Dordrecht

Hippel E (1986) Lead user: a source of novel product concepts. Manage Sci 32:791-805. doi: $10.1287 / \mathrm{mnsc} .32 .7 .791$

Hornbostel S (2001) Third party funding of German universities. An indicator of research activity. Scientometrics 50:523-537. doi:10.1023/A:1010566916697

Jacobs J (1969) The economy of cities. Vintage, New York

Jaffe A (1989) Real effects of academic research. Am Econ Rev 79:957-970

Kalirajan KP, Shand RT (1999) Frontier production functions and technical efficiency measures. J Econ Surv 13:149-172. doi:10.1111/1467-6419.00080

Kline SJ (1985) Innovation is not a linear process. Res Manage 28:36-45

Kline SJ, Rosenberg N (1986) An overview of innovation. In: Landau R, Rosenberg N (eds) The positive sum strategy. National Academy Press, Washington pp 275-305

Koenker R, Bassett G (1982) Robust tests for heteroscedasticity based on regression quantiles. Econometrica 50:43-61. doi:10.2307/1912528

Lawson C, Lorenz E (1999) Collective learning, tacit knowledge and regional innovative capacity. Reg Stud 33:305-317. doi:10.1080/713693555

Leibenstein H (1966) Allocative efficiency vs. "X-efficiency". Am Econ Rev 56:392-415

Leydesdorff L, Fritsch M (2006) Measuring the knowledge base of regional innovation systems in Germany in terms of a triple helix dynamics. Res Policy 35:1538-1553. doi:10.1016/j.respol.2006.09.027

Marshall A (1890) Principles of economics. Macmillan, London

Maskell P, Malmberg A (1999) Localized learning and industrial competitiveness. Camb J Econ 23:167-185. doi:10.1093/cje/23.2.167

Mowery DC, Oxley JE, Silverman BS (1998) Technological overlap and interfirm cooperation: implications for the resource-based view of the firm. Res Policy 27:507-523. doi:10.1016/S0048-7333(98)00066-3

Muller E, Zenker A (2001) Business services as actors of knowledge transformation: the role of KIBS in regional and national innovation systems. Res Policy 30:1501-1516. doi:10.1016/S0048-7333(01)00164-0

Ouwersloot H, Rietveld P (2000) The geography of R\&D: tobit analysis and a Bayesian approach to mapping R\&D activities in the Netherlands. Environ Plan A 32:1673-1688. doi:10.1068/a3336

Paci R, Usai S (1999) Externalities, knowledge spillovers and the spatial distribution of innovation. Geo J 49:381-390. doi:10.1023/A:1007192313098

Paci R, Usai S (2000a) Technological enclaves and industrial districts: an analysis of the regional distribution of innovative activity in Europe. Reg Stud 34:97-114. doi:10.1080/00343400050006032

Paci R, Usai S (2000b) The role of specialization and diversity externalities in the agglomeration of innovative activities. Riv Ital Econ 2:237-268

Porter ME (1998) Clusters and the new economics of competition. Harv Bus Rev 76:77-90

Rogers WH (1993) Calculation of quantile regression standard errors. Stata Tech Bull 13:18-19

Romer PM (1986) Increasing returns and long run growth. J Polit Econ 94:1002-1037. doi:10.1086/261420

Ronde P, Hussler C (2005) Innovation in regions: what does really matter? Res Policy 34:1150-1172. doi:10.1016/j.respol.2005.03.011

Urban GL, Hippel E (1988) Lead user analyses for the development of new industrial products. Manage Sci 34:569-582. doi:10.1287/mnsc.34.5.569

van der Panne G (2004) Agglomeration externalities: Marshall versus Jacobs. J Evol Econ 14:593-604. doi:10.1007/s00191-004-0232-x

van Oort F (2002) Innovation and agglomeration economies in the Netherlands. J Econ Soc Geogr 93: $344-360$ 